\title{
PREVALENCE OF COXIELLA BURNETII INFECTION IN MILITARY TRAINING AREAS IN THE CZECH REPUBLIC AND SLOVAKIA
}

\section{LITERÁK}

\author{
Department of Infectious Diseases and Epizootiology, Faculty of Veterinary Medicine, \\ University of Veterinary and Pharmaceutical Sciences, 61242 Brno \\ Received October 17, 1994 \\ Accepted May 30, 1995
}

\begin{abstract}
L i t e rá k I.: Prevalence of Coxiella burnetii Infection in Military Training Areas in the Czech Republic and Slovakia. Acta vet. Brno 1995, 64:179-186.

Between 1987 and 1992, the presence of antibodies to the $Q$ fever agent was investigated in seven military training areas (MTA) on the territory of the Czech republic and Slovakia. Using a complement fixation test (CFT), antibodies in cattle were confirmed (Coxiella burnetii, phase II, titer $\geq 8$ ) in two MTA, and in small ground mammals in five MTA. In one MTA, the $C$. burnetii strain was isolated from cow milk. No antibodies were found in enlisted soldiers, horses, sheep, dogs or game. The presence of $C$. burnetii strains under the specific MTA conditions has been demonstrated and it is possible that people in those areas may be infected. The risk of infection, however, is the same as in a civilian environment. It seems that the virulence of $C$. burnetii strains circulating in MTA is relatively low.
\end{abstract}

Coxiella burnetii, antibodies, complement fixation test, military training areas, soldiers, cattle, sheep, small mammals, game

Military training areas (MTA) are large areas that have been used by the army forces for a long time. Some parts of those facilities have been extensively damaged by military activities, while others are well-preserved because they have been practically off-limits for the non-military, with farming and forest exploitation restricted to a minimum. The specific uses of MTA bring soldiers to a close contact with the environment inhabited by wild and, in some cases, domestic animals. This exposes the soldiers and animals to the risk of a contact with circulating zoonosis agents. These may occur in the environment, or may have been brought there recently by incoming soldiers or farm animals.

$\mathrm{Q}$ fever is a zoonosis, the causative agent of which, Coxiella burnetii, occurs in Central Europe in the nature, e.g. in ticks and reservoir wild mammals, as well as in places related to human activities, namely in herds of domestic animals, mainly cattle and sheep ( $\check{R}$ e h á c e k 1987). The aim of the present paper was to investigate a number of military training areas for the presence of the rickettsiae of Coxiella burnetii, indirectly by serological examination and by direct isolation, and to assess the risks of infection for people in this environment.

\section{Materials and Methods}

The study was carried out in seven military training areas:

1. Mimon MTA in northern Bohemia. Area over 30 thousand ha, about half of which covered with forests. Cattle and horses production. Mimon MTA is extensively poluted with oil products as a result of a long presence of the ex-Soviet Union troops.

2. Libavá MTA in northern Moravia. Area over 30 thousand hectares (ha), with almost $90 \%$ covered with forests. Cattle production.

3. Jince MTA in central Bohemia. Area about 25 thousand ha. Almost $90 \%$ of the area are forests. No animal production. 
4. Boletice MTA in southern Bohemia. Area over 20 thousand ha, almost $60 \%$ of which are forests. Cattle and sheep production.

5. Vyškov MTA in southern Moravia. Area about 15 thousand ha, more than 13 thousand ha covered with forests. No animal production.

6. Hartmanice MTA in southern Bohemia. Area almost 20 thousand ha, forests about 17 thousand ha. Cattle production, some pigs and sheep.

7. Pliešovce MTA in central Slovakia. Large area partially covered with forests. Cattle and sheep production. In MTA 1 to 6, which are now situated on the territory of the Czech Republic, the study was made from 1987 to 1989. In MTA 2 and 7, tests were made in 1991 and 1992. MTA 7 is now situated on the territory of the Slovak Republic.

Enlisted soldiers were examined in MTA 2 and 7.

Domestic and farm animals examined were cattle, sheep, horses and dogs. Cattle was examined in MTA 2, 4, 6 and 7, sheep and dogs in MTA 7, and horses in MTA 2.

Small mammals were caught using spring traps arranged in lines per 100 traps each. Seven such lines were usually placed at different locations in training areas for two nights in May, September and November. Antibodies to $C$. burnetii were examined in the so-called eluates, substances separated by elution from split hearts in $1 \mathrm{ml}$ buffered physiological saline. The eluate was used like serum in a 1:10 dilution. Small mammals were examined in MTA 1-6.

In game from military training areas, blood was collected from individual animals immediately after they were killed and tests were made of their blood serum. Game animals were examined in training areas 1-6.

\section{Serological examination}

The complement fixation micromethod with antigen to phase II of the C. burnetii Nine Mile strain was used in all serologic examinations (Bodibion, MEVAK Nitra, Slovak Republic).

\section{Isolation assay of Coxiella burneti}

Cows in MTA 7 were tested by injecting $1 \mathrm{ml}$ of milk from selected cows intraperitoneally to serologically negative laboratory mice of a Swiss strain. Two of four mice were sacrificed three weeks after the milk had been injected, and impression preparations of their spleens were made and stained for a coxiella assay according to Giménez. Spleens were then frozen to $-18{ }^{\circ} \mathrm{C}$. The remaining two mice were sacrificed 6 weeks after the milk was injected, and their blood was collected at that time for serological examination. Impression preparations from spleens of these mice were also stained. Spleens of the first two mice were thawed, mixed with the spleens of the other two mice and a suspension was made of them and buffered physiological saline. This was injected intraperitoneally (second passage) to two laboratory mice ( $1 \mathrm{ml}$ each). The mice were sacrificed one week later, impression preparations from their spleens were stained, and the passage repeated. Repeated passages were made of samples which had caused seroconversion in mice after injection.

\section{Results}

\section{Military Personnel}

Examinations were made in the Libavá and Pliešovce training areas, with a total of 72 and 30 soldiers respectively. No antibodies to C. burnetii were detected in any of the tests (Tab. 1 and 2).

Table 1

Results of serologic examinations for antibodies to C. burnetii in Libavá MTA in 1991 and 1992

\begin{tabular}{|l|c|c|c|}
\hline & $\begin{array}{l}\text { No. of } \\
\text { tests }\end{array}$ & $\begin{array}{l}\text { No. of } \\
\text { positive tests }\end{array}$ & $\begin{array}{c}\text { CFT } \\
\text { Titres }\end{array}$ \\
\hline People & 72 & 0 & - \\
\hline Cattle & & & \\
Czech Spotted & 136 & $7(5.1 \%)$ & $\begin{array}{c}2 \times 8.3 \times 16.2 \times 32 \\
8,16,64 \\
\text { Cows } \\
\text { Calves } \\
\text { Hereford }\end{array}$ \\
\hline Horses & 35 & 3 & - \\
& 14 & 0 & - \\
\hline
\end{tabular}


Table 2

Results of serologic examinations for antibodies to $C$. burnetii in Pliešovce MTA in 1991 and 1992

\begin{tabular}{|l|c|c|c|}
\hline & $\begin{array}{l}\text { No. of } \\
\text { tests }\end{array}$ & $\begin{array}{l}\text { No. of } \\
\text { positive tests }\end{array}$ & $\begin{array}{c}\text { CFT } \\
\text { Titres }\end{array}$ \\
\hline People & 30 & 0 & - \\
\hline $\begin{array}{l}\text { Cattle (cows) } \\
1991 \\
\text { on-vaccinated }\end{array}$ & 127 & $27(21.3 \%)$ & $\begin{array}{c}7 \times 8,6 \times 16 \\
6 \times 32,5 \times 64 \\
3 \times 128 \\
15 \times 8,10 \times 16 \\
3 \times 32,2 \times 64 \\
1 \times 128\end{array}$ \\
$\begin{array}{l}1992 \\
\text { After Bodibion } \\
\text { vaccination }\end{array}$ & 129 & $31(24.0 \%)$ & - \\
\hline Sheep & & & - \\
\hline Dogs & 11 & 0 & \\
\hline
\end{tabular}

\section{Cattle}

In the Boletice and Hartmanice training areas, a total of 202 and 336 head of cattle respectively were examined, and no antibodies were found.

In the Libavá MTA, a 5.1\% prevalence of antibodies was ascertained in a production herd of the Czech Spotted Cattle. No antibodies were found in a Hereford herd, quarantined there after arrival from Canada (Tab. 1).

In 1991, when cattle was not vaccinated against $Q$ fever, antibodies were found in $21.3 \%$ of the Pliešvce MTA cattle, a local breed reared in traditional cowsheds. When, independently of our investigation, the high seroprevalence of antibodies to $Q$ fever in the Pliešovce area was ascertained by the State Veterinary Institute in Zvolen, local veterinary authorities decided that all the cattle should be vaccinated against Q fever in early 1992 (Bodibion vaccine, i.e. C. burnetii in phase I). In 1992, antibodies were found in $24 \%$ of the cows tested (Tab. 2). In the tests, CFT with a phase II antigen was used (the CFT used does not detect the postvaccination antibodies to phase I antigen). In the Pliešovce MTA, no statistically significant difference was found between the 1991 and 1992 incidence of antibodies $\left(\chi^{2}\right.$ test, $\left.\chi^{2}=0.36,1 \mathrm{df}, \mathrm{P}>0.5\right)$. A statistically highly significant difference was, on the other hand, found in seroprevalence of antibodies to $Q$ fever between the Libavá and the Pliešovce MTA cattle $\chi^{2}$ test, $\chi^{2}=$ 20.7, $1 \mathrm{df}, \mathrm{P}<0.001)$.

In isolation tests of milk from 24 cows, the $C$. burnetii strain was detected in 4 cows by a seroconversion in laboratory mice which had been injected with the milk tested. The $C$. burnetii strain was directly detected in the spleen of experimental mice in two cases (Tab. 3).

\section{Sheep,Horses and Dogs}

A total of 53 sheep and 11 dogs from the Pliešovce MTA and 14 horses from the Libavá MTA were tested. In all these cases, results were negative (Tabs 1 and 2).

\section{S mall Mammals}

A total of 1.486 small mammals were tested. In 12 cases $(0.8 \%)$, antibodies to C. burnetii were detected (Tab. 4). In small mammals, antibodies were found in five of the six military training areas surveyed. The seroprevalence ranged from $0.3 \%$ to $1.9 \%$. Antibodies 
were detected in 11 specimens of the Apodemus sp. and 1 specimen of Microtus arvalis (Tab. 5). Small mammals with antibodies to $C$. burnetii were usually trapped in places used by man or domestic animals.

Game animals

No antibodies to $C$. burnetii were detected (Tab. 6) in any of the 169 animals hunted in MTA 1 to 6 (Tab. 6).

Table 3

Results of isolation surveys of cow milk from two farms in Pliešovce MTA to assay the strain of $C$. burnetii (K.V. - Kamenný Vrch Farm, V.V. - Vidov Vrch Farm)

\begin{tabular}{|r|c|c|c|}
\hline Cow No. & $\begin{array}{l}\text { Titres } \\
\text { of antibodies } \\
\text { in cows (a) }\end{array}$ & $\begin{array}{l}\text { Antibody } \\
\text { prevalence } \\
\text { in mice (b) }\end{array}$ & $\begin{array}{l}\text { C. burnetii } \\
\text { incidence } \\
\text { in mice (c) }\end{array}$ \\
\hline 1 K.V. & - & - & -1 st passage \\
2 K.V. & - & - & -1 st passage \\
3 K.V. & - & - & -1 st passage \\
4 K.V. & - & - & -1 st passage \\
5 K.V. & 8 & - & -1 st passage \\
6 K.V. & 8 & - & -1 st passage \\
7 K.V. & 8 & - & -1 st passage \\
8 V.V. & 8 & - & -1 st passage \\
9 K.V. & 16 & - & -1 st passage \\
10 V.V. & 16 & - & -1 st passage \\
11 K.V. & 16 & - & -1 st passage \\
12 V.V. & 16 & - & -1 st passage \\
13 V.V. & 16 & - & -1 st passage \\
14 V.V. & 16 & + & -8 th passage \\
15 K.V. & 32 & - & -1 st passage \\
16 V.V. & 32 & - & -1 st passage \\
17 K.V. & 32 & + & +4 th passage \\
18 V.V. & 32 & +6 th passage \\
19 V.V. & 64 & - & -1 st passage \\
20 K.V. & 64 & - & -8 th passage \\
21 K.V. & 128 & - & -1 st passage \\
22 V.V. & 128 & -1 st passage \\
23 V.V. & 128 & -1 passage \\
24 V.V. & 128 & -1 st passage \\
\hline
\end{tabular}

a - CFT of antibodies in cows at the e of milk collection (October 1991)

b - CFT of antibodies in mice 6 weeks after i.p. injection with infected milk

c - impression preparations of the spleen stained according to Giménez, speen suspension passaged i.p. every 6 days

d - strain identification confirmed by the WHO reference laboratory (Virological Institute of the SAS, Bratislava, Slovak Republic) 
Table 4

Antibodies to $C$. burnetii in small mammals in individual MTA between 1987 and 1989

\begin{tabular}{|c|c|c|c|c|c|c|}
\hline \multirow[t]{2}{*}{ Species } & \multicolumn{5}{|c|}{$\begin{array}{l}\text { Prevalence of antibodies } \\
\text { Positive/Total tests }\end{array}$} & \multirow[b]{2}{*}{6} \\
\hline & MTA 1 & 2 & 3 & 4 & 5 & \\
\hline $\begin{array}{l}\text { Common Vole } \\
\text { Microtus arvalis }\end{array}$ & $0 / 20$ & $1 / 38$ & $0 / 17$ & $0 / 134$ & $0 / 70$ & $1 / 54$ \\
\hline $\begin{array}{l}\text { Field Vole } \\
\text { M. agrestis }\end{array}$ & & $0 / 2$ & $0 / 9$ & $0 / 1$ & & $0 / 3$ \\
\hline $\begin{array}{l}\text { Bank Vole } \\
\text { Clethrionomys glareolus }\end{array}$ & $0 / 52$ & $0 / 3$ & $0 / 23$ & $0 / 12$ & $0 / 13$ & $0 / 17$ \\
\hline $\begin{array}{l}\text { Field Mouse } \\
\text { Apodemus sp. }\end{array}$ & $4 / 87$ & $0 / 92$ & $2 / 126$ & $1 / 99$ & $0 / 155$ & $1 / 114$ \\
\hline $\begin{array}{l}\text { Striped Field Mouse } \\
\text { A. agrarius }\end{array}$ & $0 / 8$ & 2/96 & & $0 / 2$ & & \\
\hline $\begin{array}{l}\text { House Mouse } \\
\text { Mus musculus }\end{array}$ & $0 / 2$ & & & & $0 / 1$ & \\
\hline $\begin{array}{l}\text { Norway Rat } \\
\text { Rattus norvegicus }\end{array}$ & $0 / 3$ & & & & & \\
\hline $\begin{array}{l}\text { Common Dornmouse } \\
\text { Muscardinus avellanarius }\end{array}$ & & & $0 / 1$ & & & \\
\hline $\begin{array}{l}\text { Common Shrew } \\
\text { Sorex araneus }\end{array}$ & $0 / 39$ & $0 / 30$ & $0 / 39$ & $0 / 64$ & $0 / 16$ & $0 / 28$ \\
\hline $\begin{array}{l}\text { Pygmy-Shrew } \\
\text { Sorex minutus }\end{array}$ & $0 / 2$ & & $0 / 8$ & $0 / 2$ & & \\
\hline $\begin{array}{l}\text { Lesser White-Toothed Shrew } \\
\text { Crocidura suaveolens }\end{array}$ & & & & $0 / 2$ & & \\
\hline $\begin{array}{l}\text { Water-Shrew } \\
\text { Neomys fodiens }\end{array}$ & & & & $0 / 1$ & & \\
\hline $\begin{array}{l}\text { Total } \\
\%\end{array}$ & $\begin{array}{l}4 / 213 \\
1.9\end{array}$ & $\begin{array}{l}3 / 261 \\
1.2\end{array}$ & $\begin{array}{l}2 / 223 \\
0.9\end{array}$ & $\begin{array}{l}1 / 315 \\
0.3\end{array}$ & $\begin{array}{l}0 / 258 \\
0.0\end{array}$ & $\begin{array}{l}2 / 216 \\
0.7\end{array}$ \\
\hline
\end{tabular}

Table 5

List of small mammals with antibodies to $C$. burnetii

\begin{tabular}{|c|c|c|c|c|}
\hline MTA & Date & Species & Titre & Location of traps \\
\hline 1 & Sep. 1987 & Apodemus sp. & 10 & Log cabin \\
\hline 1 & $-1 /-$ & $-/ /-$ & 10 & Farm \\
\hline 1 & $-1 /-$ & $-1 /-$ & 10 & $-11-$ \\
\hline 1 & Nov. 1988 & $-1 /-$ & 10 & Pasture \\
\hline 2 & Sep. 1987 & Microtus arvalis & 10 & Log cabin \\
\hline 2 & Sep. 1988 & Apodemus agrarius & 10 & Rubbish heap \\
\hline 2 & Nov. 1989 & $-/ /-$ & 320 & Log cabin \\
\hline 3 & Sep. 1987 & Apodemus sp. & 10 & Rubbish heap \\
\hline 3 & $-\| / 1-$ & $-/ /-$ & 10 & $-1 /-$ \\
\hline 4 & $-11-$ & $-11-$ & 10 & Forest edge \\
\hline 6 & Nov. 1987 & $-11-$ & 40 & Log cabin \\
\hline 6 & $-11-$ & $-11-$ & 20 & $\begin{array}{l}\text { Chemical warfare } \\
\text { training area }\end{array}$ \\
\hline
\end{tabular}


Table 6

Results of game survey for antibodies to $C$. burnetii (results of all tests were negative)

\begin{tabular}{|c|c|c|c|c|c|c|}
\hline Species & MTA 1 & 2 & 3 & 4 & 5 & 6 \\
\hline $\begin{array}{l}\text { Red Deer } \\
\text { Cervus elaphus }\end{array}$ & 1 & 40 & 7 & 7 & 13 & 32 \\
\hline $\begin{array}{l}\text { Roe Deer } \\
\text { Capreolus capreolus }\end{array}$ & & 7 & & 11 & 3 & 4 \\
\hline $\begin{array}{l}\text { Fallow Deer } \\
\text { Dama dama }\end{array}$ & 2 & & & & & \\
\hline $\begin{array}{l}\text { Hog } \\
\text { Sus scrofa }\end{array}$ & 1 & 7 & 3 & 8 & 14 & 3 \\
\hline $\begin{array}{l}\text { European Hare } \\
\text { Lepus europaeus }\end{array}$ & & 1 & & & & \\
\hline $\begin{array}{l}\text { Common Red Fox } \\
\text { Vulpes vulpes }\end{array}$ & & 3 & & & & \\
\hline $\begin{array}{l}\text { Pine-Marten } \\
\text { Martes martes }\end{array}$ & & & & & & 1 \\
\hline Total & 4 & 58 & 10 & 26 & 30 & 40 \\
\hline
\end{tabular}

\section{Discussion}

The prevalence of antibodies to $\mathrm{Q}$ fever in the population of the Czech Republic is at

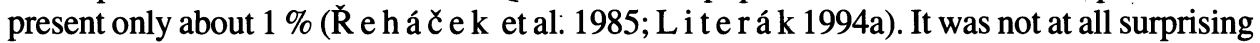
that no antibodies were found in the 72 people from the Libavá MTA or the 32 people from the Pliešovce MTA, particularly because these people (draftees doing their national service) did not get into any close contact with potentially infected cattle.

In recent years, a generalized prevalence of antibodies to C. burnetii in cattle herds in the Czech Republic and Slovakia has been observed. Antibodies to $C$. burnetii have also been found in small mammals in several areas ( $\breve{R}$ e h á č e k et al. 1979, 1985, 1987ab; Ř e há č e k 1987; L i sák et al. 1989; V o š t a et al. 1988, 1989; C e m p ír k o vá et al. 1993; L i t e r á k 1994b, 1995; L i t e r á k and Calvo R o d r í g u e z 1994). Similar situation also exists in neighbouring central European countries (C y $\mathrm{g}$ a $\mathrm{n}$ et al. 1983; S c hwe i g hard t et al. 1984; R a d y et al. 1985; K r a u s s et al. 1987; K e há č e k et al. 1993). For that reason, we really cannot consider the finding of antibodies to $C$. burnetii in cattle and small mammals in Czech and Slovak military training areas as something unusual. The prevalence, however, is a proof that the agent of the zoonosis circulates both in cattle herds, i.e. close to human settlements, and in the nature. The importance of these findings depends mainly on the virulence of autochthonous strains of $C$. burnetii. In the herds in the training facilities investigated, no clinical symptoms of $Q$ fever were found. In cattle herds with seroprevalence of antibodies to $C$. burnetii on civilian farms, we observe, for the most part, latent infections without any clinical manifestations. No relationship was confirmed, for example, between abortions in the cattle in southern Moravia and seroprevalence of antibodies to C. burnetii ( $\mathrm{L}$ i t e r á k and $\mathrm{R} \mathrm{o} \mathrm{d} \mathrm{r} \mathrm{íg} \mathrm{u} \mathrm{e} \mathrm{z} \mathrm{1994).} \mathrm{An} \mathrm{in-}$ dispensable prerequisite for an epidemiological and epizootiological evaluation of antibody findings is an isolation of $C$. burnetii strains and testing their virulence in experimental infections. It seems that strains of $C$. burnetii currently circulating in Moravia are less virulent 
for laboratory animals than the standard $C$. burnetii strain, i.e. the Nine Mile strain (V a l k o vá et al. 1994).

The fact that prevalence of antibodies in the Libavá MTA cattle was significantly lower than in the Pliešovce MTA can be explained by objective differences between $\mathrm{Q}$ fever in cattle in the Czech Republic and Slovakia ( $\check{R}$ e h á c e k 1987). In the Czech Republic, prevalence is lower than in Slovakia, and so is probably virulence of autochthonous circulating strains of $C$. burnetii. It is assumed that the reason is the incidence of Dermacentor marginatus, the tick that is an important vector and reservoir of coxiellas. Dermacentor marginatus occurs mainly in southern areas of central Slovakia, including also the Zvolen district where the Pliešovce MTA is situated. In northern Moravia, where the Libavá MTA is, Dermacentor marginatus does not occur.

In cattle herds with a level of seroprevalence of antibodies to $C$. burnetii, coxiellas are excreted in milk. In the Pliešovce MTA, coxiellas were found in 4 out of 24 milk samples. However, normal excretion of $C$. burnetii by latently infected cows was reported by, e.g., $\mathrm{R} \mathrm{e} \mathrm{u} \mathrm{s} \mathrm{c} \mathrm{h} \mathrm{(1982)} \mathrm{or} \mathrm{S} \mathrm{c} \mathrm{h} \mathrm{a} \mathrm{a} \mathrm{l} \mathrm{and} \mathrm{S} \mathrm{c} \mathrm{h} \mathrm{a} \mathrm{f} \mathrm{e} \mathrm{r} \mathrm{(1989).} \mathrm{This} \mathrm{fact,} \mathrm{however,} \mathrm{is} \mathrm{not} \mathrm{assumed}$ to have much importance for human health (D u r a n d and L i m o u z i n 1983).

The prevalence of antibodies to $C$. burnetii in small mammals deserves particular attention. After all, infected specimens were found in five out of six military training areas investigated at places which, like, e.g., log cabins, rubbish heaps, farm, shooting range, were related man's activities. In unaffected areas of the countryside, however, antibodies to $C$. burnetii were absent not only from small mammals but also from game. Very similar results in small mammals at municipal waste dumps in southern Bohemia were reported by $\mathrm{V} l \check{c} \mathrm{e} \mathrm{k}(1991)$. The sources of infection, which might play a role in human infections, as well as the origin and virulence of individual strains of $C$. burnetii, are some of the questions to which answers must be sought.

\section{Výskyt infekcí způsobovaných riketsií Coxiella burnetii ve vojenských výcvikových prostorech v Ceské republice a na Slovensku}

V letech 1987-1992 byly v sedmi vojenských výcvikových prostorech (VVP) na území dnešní České republiky a Slovenska sledovány protilátky proti původci $Q$ horečky. Protilátky byly prokázány komplementfixační reakcí (antigen Coxiella burnetii ve fázi II, titr $\geq$ 8) u skotu ve dvou VVP a u drobných zemních savcủ v pěti VVP. Kmen C. burnetii byl izolován z mléka krav v jednom VVP. Protilátky nebyly prokázány u vojákủ základní služby, koní, ovcí, psủ a lovné zvěre. Ve specifických podmínkách VVP kmeny $C$. burnetii cirkulují a existuje tedy možnost infekce lidí v těchto oblastech. Tato možnost infekce se však neliší od možnosti infekce v civilním sektoru. Virulence kmenů $C$. burnetii cirkulujících ve VVP je zřejmě poměrně nízká.

\section{References}

CEMPIRKOVÁ R., ŘEHÁČEK J., LISÁK V. 1993: Protilátky proti Coxiella burnetii a Chlamydia psittaci v některých vybraných chovech skotu v jižních Cechách. Sborník Jihođeské university Zemědělské fakulty v Ceských Budejovicích, 10:51-661

CYGAN Z., BUCZEK J., MODZELEWSKA A., GUZIK Z. 1983: Ognisko goracki Q rozpoznane serologiczne w stadzie krów mlecznych. Med. weter. 39:536-538

DURAND M. P., LIMOUZIN C. 1983: Un probléme đ hygiéne alimentaire: ápropos du risque potentiel du lait de vaches infectées par Coxiella burnetii sur la santé humaine. Bull. Acad. vétér. France 56: 475-485

KRAUSS H., SCHMEER N., SCHIEFER H. G. 1987: Epidemiology and the significance of $Q$ fever in the Federal Republic of Germany. Zbl. Bakt. Hyg. A. 276: 42-50 
LISÁK V., VOŠTA J., ŘEHÁČEK J. 1989: Výskyt Coxiella burnetii a Chlamydia psittaci u hovädzieho dobytka v južných Čechách. Veter. Med. (Praha ) 34: 403-410

LITERÁK I. 1994: Prevalence of antibodies to Coxiella burnetii in blood donors in the Czech Republic. Centr. eur. J. publ. Hlth 2:52-54

LITERÁK I. 1995: Výskyt protilátek proti Coxiella burnetii u skotu, ovcí a drobných zemních savcủ v západních Cechách. Veter. Med. (Praha) 40:77-80

LITERÁK I. 1994: Coxiella burnetii antibodies in calves concentrated in a large-capacity calf house in an area with endemic incidence of latent bovine $Q$ fever. Acta vet. Brno 63:65-69

LITERÁK I., CALVO RODRIGUEZ B. 1994: Latent Q fever in cattle in Southern Moravia (Czech Republic). Centr. eur. J. publ. Hlth, 2: 91-94

RADY M., GRÁVITS R, NAGY G. V: Demonstration in Hungary of $Q$ fever associated with abortions in cattle and sheep. Acta veter. Hung. 33:169-176

REUSCH C. 1982: Vergleichsuntersuchungen mit dem Meerschweinchen - und Mäusetest zum Nachweis von Coxiella burnetii - zugleich eine Studie über die Verbreitung des Q - Fiebers in Süd - und Mittelhessen. Dissertation, Universität Giessen 133p.

ŘEHÁCEK J. 1987: Epidemiology and significance of Q fever in Czechoslovakia. Zbl. Bakt. Hyg. A 267:16-19

ŘEHÁCEK J., BREZINA R., KAŠPAR H., PUSTÓWKA V., MAĎAR J.1979: Př́spěvek k infestaci skotu rickettsiemi a chlamydiemi ve dvou oblastech CSSR. Veterinárství 29:542-544

ŘEHÁĆEK J., VOŠTA J., BREZINA R., HANÁK P. 1985: Rickettsiae in the Sumava region. Folia parasitol. 32:173-183

ŘEHÁČEK J., VOŠTA J., KOCIANOVÁ E., LISÁK V., HANÁK P., KOVÁC̆OVÁ E., CEMPIRKOVÁ R. 1987: Výskyt koxiellózy a chlamydiózy na Šmavě. Veter. Med. (Praha) 32:279-288

ŘEHÁČEK J., PEJČOCH M., LISÁK V., PŘ́fVOROVÁ A., LOKAJ J., KAZÁR J., PEJČOCHOVÁ J. 1987: Případ Q-horeckky na Moravě. Českoslov. Epidem. Mikrobiol. Imunol. 36: 280- 286

ŘHEÁCEK J., KRAUSS H., KOCIANOVÁ E., KOVÁČOVÁ E., HINTERBERGER G., HANÁK P., TƯMA V. 1993: Studies of the prevalence of Coxiella burnetii, the agent of $Q$ fever, in the foothills of the Southern Bavarian Forest, Germany. Zbl. Bakt. 278:132-138

SCHAAL E. H., SCHAFER J. 1984: Zur Verbreitung des Q - Fiebers in

einheimischen Rinderbeständen. Dtsch. tierärztl. Wschr. 91:52-56

SCHWEIGHARDT H., PECHAN P., LAUERMANN E. 1984: Q - Fieber und Haemophilus somnus - Infektionen vergleichsweise seltene Verwerfensursachen beim Rind. Tierärztl. Umsch. 39:581-582

VALKOVÁ D., KOCIANOVÁ E., KOVÁCOVÁ E., LITERÁK I. 1994: Plasmid typing and virulence of Coxiella burnetii isolates. Abstract book, 7th International Congress of Bacteriology and Applied Microbiology Division, Prague, Czech Republic, July 3rd-8th p. 217

VLČEK M. 1991: Drobní savci na skládkách komunálních odpadů jako rezervoáry patogenů a parazitů. Veter. Med. (Praha) 36:569-575

VOŠTA J., ŘEHÁČEK J., HANÁK P., TƯMA V. 1988: Výskyt protilátek proti leptospirám a Coxiella burnetii u drobných savcủ nivy Horní Lužnice. Sborník Vysoké školy zemědělské Praha Agronomické fakulty v Českých Budějovicích, raada fytotechnická 2:141-148

VOŠTA J., ŘEHÁČEK J., LISÁK V. 1989: Q horeð̌ka na Třeboňsku. Sbor. Vys. Šk. zeměd. Praha, Agron. Fac. České Budějovice, rada zootechnická 3:109-117 